\title{
ANTROPOMETRIAI PARAMÉTEREK DIAGNOSZTIKUS HATÉKONYSÁGA AZ ELHÍZÁS, KÜLÖNÖS TEKINTETTEL A ZSIGERI ZSÍRFELHALMOZÓDÁS ÉS BIZONYOS KARDIOVASZKULÁRIS RIZIKÓTÉNYEZŐK TÜKRÉBEN
}

\author{
Pintér Zoltán \\ Szegedi Tudományegyetem, Embertani Tanszék, Szeged \\ Témavezetők: Dr. Pálfi György és Dr. Varga Csaba
}

Pintér Z.: Diagnostic efficiency of anthropometric parameters in the detection of obesity, with special regard to visceral adiposity and certain cardiovascular risk factors. The visceral adipose tissue carries greater risk of developing cardio-metabolic disorders than subcutaneous adipose tissue or whole-body obesity. Estimating fat distribution and intra-abdominal fat accumulation could be more useful to predict the risk of cardio-vascular and metabolic diseases than whole body fat. The indices and models to estimate the distribution and amount of adipose tissue, which are based on body measurements, do not distinguish visceral tissue from subcutaneous abdominal adipose tissue. It is of high importance to validate the predictive accuracy of existing, indirect methods in relation to the accumulation and localization of adipose tissue and cardio-metabolic risk factors, and to develop new, inexpensive and reliable methods for clinical use. The main aims and questions were the followings: (1) To determine which anthropometric parameters have strong relation with visceral fat accumulation (VFA)? (2) To identify the anthropometric parameters having the best ability to estimate VFA. (3) To evaluate the relationships between changes in body fat content, VFA and anthropometric parameters. (4) How reliable are the investigated anthropometric parameters in the identification of cardiovascular risk factors?

Keywords: Body fatness estimation; Cardio-vascular risk factors; Visceral fat accumulation.

\section{Bevezetés}

Az elhízás, ami a szervezet kóros mértékủ zsírfelhalmozódását jelenti, járványszerü méreteket öltött mind a fejlett, mind pedig a fejlödő országokban. Az elmúlt évtizedek során az elhízottak aránya jelentős mértékben megnövekedett, és ez a trend napjainkban is folytatódik. Ráadásul ez a probléma nem csak a felnőtteket érinti, hanem a gyerekek és a serdülőkorúak körében is egyre nagyobb egészségügyi kihívást jelent. Számos életet veszélyeztető, krónikus betegség kialakulása hozható összefüggésbe az elhízással, mint például a szív-érrendszeri rendellenességek, a 2-es típusú cukorbetegség, mozgásszervi elváltozások és a rák különbözö fajtái.

Számos vizsgálat alátámasztja, hogy a zsigeri zsírszövet fokozottabb kockázatot jelent a különféle kardiometabolikus rendellenességek kialakulásának szempontjából, mint a bör alatt elhelyezkedö zsírszövet, vagy a test teljes zsírtartalma. Következésképpen, a zsírszövet eloszlásának és az intraabdominális zsír mennyiségének becslése hasznosabb és pontosabb információt szolgáltathat a kardiovaszkuláris és metabolikus kockázatról.

A jelenleg rendelkezésünkre álló technikák közül a kettős foton abszorpciometria (DXA), a komputer tomográfia (CT) és a mágneses rezonancia mérésén alapuló képalkotás (MRI) biztosítják a legpontosabb in vivo módszereket a zsigeri zsír 
mennyiségének mérésére. Használatuk azonban a rutin klinikai gyakorlatban nehezen kivitelezhető, mivel módfelett idő- és költségigényesek, ráadásul a DXA és CT technikák potenciális sugárzásnak teszik ki a vizsgált személyeket. Mindezek következtében számos alternatív eljárást dolgoztak ki a zsigeri zsír akkumulációjának meghatározására. $\mathrm{Az}$ ultraszonográfia egyike azon módszereknek, amelyet megfelelően pontos és megbízható technikának találtak az intraabdominális zsírszövet és a következményes szív-érrendszeri kockázat felbecslése szempontjából. A bioelektromos impedancia analízis (BIA) egyre szélesebb körben elterjedt, egyszerü, nem invazív és viszonylag olcsó módszer a szervezet zsírtartalmának meghatározására, habár a mérés pontosságát számos tényező befolyásolhatja.

Egyszerüségüknek köszönhetően a klinikai gyakorlatban és az epidemiológiai vizsgálatokban különféle antropometriai paraméterek használata vált elterjedtté, mint az elhízás meghatározásának közvetett módszerei. Míg a testtömegindex (BMI) kiszámítása egy közkedvelt mód az általános tápláltsági állapot becslésére, a derékkerület, a derékcsípő arány (WHR) és a szagittális abdominális átmérö (SAD) a centrális elhízás gyakran használt indikátorai. A tapasztalat azt mutatja, hogy ezek a paraméterek képesek megfelelő hatékonysággal becsülni az abdominális zsírszövetet és a szív-érrendszeri kockázatot is. Ezeken az általánosan használt mérőszámokon kívül az elmúlt időszakokban különféle testméreteken alapuló indexek és modellek egész sorozatát alkották meg azzal a céllal, hogy minél egyszerübben, de megbízható pontossággal detektálják az elhízás mértékét, megbecsüljék a zsírszövet eloszlását és mennyiségét. A legföbb probléma ezekkel a módszerekkel, hogy nem tesznek különbséget a zsigeri régiókban elhelyezkedő és a szubkután, abdominális zsírszövet között. Ráadásul, korrelációs kapcsolatuk a zsigeri zsírterülettel és a metabolikus rendellenességekkel igen eltérő lehet különböző életkorcsoportokban és különböző elhízottsági állapot mellett.

Mindezek jól mutatják, hogy a népegészségügyi vonatkozásban is kiemelt fontosságú a már meglévő, közvetett módszerek megbízhatóságának vizsgálata a zsírfelhalmozódással, a zsírlokalizációval és a különféle kardiometabolikus rizikófaktorokkal kapcsolatban, emellett szükséges további költséghatékony, a klinikai gyakorlatban is alkalmazható, precíz eljárások kidolgozása és tesztelése.

\section{A kutatás célkitűzései}

Munkánk során a következő kérdéseket és célkitüzéseket fogalmaztuk meg: Mely antropometriai paraméterek mutatják a legerősebb kapcsolatokat a viszcerális zsírakkumulációval (VFA), az összefüggések erősségét befolyásolja-e a VFA kiterjedésének a nagysága? Meghatározni azokat az antropometriai változókat, amelyek a leginkább alkalmasak a VFA becslésére. A testzsírtartalom és a VFA mennyiségében bekövetkező változások mely antropometriai paraméterek változásával vannak leginkább összhangban? Mennyire megbízhatók a vizsgált antropometriai paraméterek bizonyos kardiovaszkuláris rizikótényezök jelenlétének diagnosztizálásában?

\section{Anyag és módszer}

A longitudinális jellegű kutatásunkban résztvevők adatait egy, az egészséges életmódot népszerüsítő kampány keretein belül gyüjtöttük össze Szegeden. Az önkéntesen jelentkező embereknek lehetőségük volt, hogy szervezett csoportok keretein belül részt vegyenek egy 4 hónapos mozgásprogramban, ahol rendszeres (legalább heti 
kétszer 1 óra), rekreatív, aerob testmozgást végeztek. Az adattisztítás során kizáró indoknak számítottak a következő tényezők: 18 év alatti életkor, terhesség, ismert krónikus és kezelést igénylö szív-érrendszeri, metabolikus és daganatos rendellenességek, az antropometriai és a testösszetétel vizsgálatokat érintő hiányos adatok. A vizsgált minta kiindulási létszáma 305 fő (67 férfi és 238 nő) volt. A mozgásprogramok végén összesen 168 személyröl (37 férfi és 131 nő) gyüjtöttünk kiértékelhető adatokat. Az antropometriai felmérések során 25 testméretet határoztunk meg. Ezek közül az elemzésekbe a következő változókat vontuk be: testmagasság, testsúly, csípőszélesség, SAD, derékkerület, csípőkerület, felkarkerület, alkarkerület, combtőkerület, alszárkerület és 6 bőrredővastagság. A BMI, a WHR, az AVI (abdominális térfogat index), a BAI (test adipozitási index), a CI (conicitás indexe), a WHtR meghatározása mellett a végtagokon mért bőrredők összegét (EST), a törzsön mért bőrredők összegét (TST) és a TST/EST hányadost (TER) is kiszámítottuk. A testösszetételt egy multifrekvenciás, nyolc ponton érintkező elektróda rendszerrel felszerelt BIA készülékkel (típus: Biospace InBody230 Body Composition Analyzer), a vérnyomást egy Omron M2 compact típusú automata felkaros vérnyomásmérővel állapítottuk meg. A laboratóriumi vizsgálatok során meghatároztuk a vérszérum glükóz, összkoleszterin, triglicerid, nagy sürüségü lipoprotein-koleszterin (HDL-C), kis sürüségü lipoprotein-koleszterin (LDL-C) és Creaktív fehérje (CRP) koncentrációját. Az adatok matematikai, statisztikai kiértékelését az SPSS for Windows (v. 17) és a MedCalc (v. 11.5) programokkal végeztük el.

\section{Vizsgálati eredmények és értékelésük}

A zsigeri zsírfelhalmozódás szempontjából, egyedülálló testméretekként a derékkerület és a SAD bizonyultak a legjobb diagnosztikus paramétereknek, míg a testméretekből származtatott indexek esetén az AVI és a WHtR tüntek a legmegbízhatóbbaknak. Általánosságban elmondható, hogy a vizsgált paraméterek többségének a predikciós hatékonysága annál jobb volt, minél jelentősebb mértékü a viszcerális zsírakkumuláció. Ezzel szemben a bőrredővastagságok a viszcerálisan nem elhízottak esetén mutattak erősebb összefüggéseket. Habár a zsigeri szempontból elhízottak körében a fentebb említett négy paraméter korrelációja a VFA-val jobb volt, detektálási hatékonyságukat kevésbé befolyásolta a VFA nagysága, szemben más gyakran használt mérőszámokkal. A derékkerület fontosságát hangsúlyozza továbbá az a tény is, hogy az AVI és a WHtR meghatározásához szükséges ezen testméret ismerete.

A regressziós analízisek eredményei is megerősítették azt a tapasztalatot, hogy az antropometriai paramétereken alapuló VFA becslés pontosabb eredményeket ad abban az esetben, ha jelentősebb mértékủ a zsigeri zsír felhalmozódása. A predikciós modellekben leggyakrabban előforduló paraméterek a derékkerület, a SAD és az életkor voltak, de emellett a becslési hatékonyság javításához kismértékben hozzájárultak egyéb testméretek (pl. combtőkerület, combredő, a csípő szélessége és kerülete) is. A becslések pontossága - korábbi szakirodalmi adatokkal összevetve - egy elfogadható tartományon belül helyezkedett el, következésképpen az antropometriai paraméterek megfelelö kombinációja egy költséghatékony, mégis kellően érzékeny módszert biztosíthat a viszcerális zsírfelhalmozódás pontos meghatározására. Egy általánosan használható modell felállításához azonban elengedhetetlen a VFA referencia módszerrel történő meghatározása és a megfelelő minta kiválasztása.

Eredményeink alapján elmondható, hogy a WHR-rel vagy a bőrredővastagságokkal szemben a testsúly, a derékkerület és a BMI egyszerü és megbízható jelzők mind a teljes 
zsírtartalom, mind a VFA mennyiségi változásainak nyomon követésére. Külön kihangsúlyozzuk a testsúly és a VFA közötti kapcsolatot, amely arra enged következtetni, hogy a testsúlygyarapodás felnőtt korban - elsősorban - a zsír, különös tekintettel a viszcerális zsír mennyiségének növekedésével jár együtt.

$\mathrm{Az}$ antropometriai paraméterek ugyan nem válthatják ki a tényleges laboratóriumi vizsgálatokat és a rizikóprofil felállítását, viszont bizonyos kockázati tényezők felmérésére és jelzésére hasznos eszközöket nyújthatnak a prevenció terén. Eredményeink szerint az elhízással összefüggésbe hozható testméretek és indexek a legszorosabb összefüggéseket a HDL-C koncentrációjával mutatták, következésképpen a rendellenes HDL-C szint identifikálásában voltak a leghatékonyabbak. Ezen kívül férfiaknál a magas CRP, nőknél a megemelkedett triglicerid szint használható prediktoroknak bizonyultak. A vizsgált változók közül a BAI, a SAD és a WHtR diagnosztikus szempontból felülmúlta a többi paramétert, ugyanakkor jelen esetben is megmutatkozott az antropometriai változók gyengesége, miszerint fokozottabb egészségügyi kockázat esetén (pl. több kardiovaszkuláris rizikótényező együttes jelenléte, nagyobb mennyiségű viszcerális zsír) predikciós képességük megbízhatóbb, szemben a kisebb mértékü rizikóval.

\section{A doktori értekezés témájában a szerző megjelent tanulmányai}

Pintér, Z., Vida, R., Németh, Zs., Just, Zs. (2009): Szegedi egyetemisták obezitás vizsgálata fizikai aktivitásuk tükrében. Természet-, Müszaki- és Gazdaságtudományok Alkalmazása 8. Nemzetközi Konferencia. Elöadások - Presentations (CD-ROM).

Pintér, Z., Báthoriné, K.A., Just, Zs. (2009): „Fiatalabbak is elkezdhetik” - középiskolások obezitás vizsgálata, fizikai aktivitása és fittsége. Elöadáskötet. pp. 37-43.

Pintér, Z., Just, Zs., Vida, E., Németh, Zs., Pálfi, Gy. (2009): The correlation between parameters indicating obesity and certain environmental factors. Acta Biol. Szeged., 53(2): 105-110.

Pintér, Z., Móricz, L., Szabó, K., Csanádi, M., Linczenbold, M., Molnár, A., Szász, A., Kiss, G., Orbán, N., Pálfi, Gy., László, F. (2011): Antropometriai jelzők kapcsolata a zsigeri elhízással. Természet-, Müszaki- és Gazdaságtudományok Alkalmazása 10. Nemzetközi Konferencia. Előadások (CD-ROM).

Pintér, Z., Vida, R., Németh, Zs., Pálfi, Gy., Just, Zs. (2011): Egyetemisták elhízottságának kapcsolata az étkezési szokásokkal és a szülők iskolázottságával. Anthrop. Közl., 52: 131-142.

Pintér, Z., Molnár, E., Kiss, G., László, F., Molnár, A., Orbán, K., Szász, A., Varga, Cs., Pálfi, Gy. (2012): Antropometriai paraméterek használhatósága felnőtt nők zsigeri zsírterületének becslésében. Anthrop. Közl., 53: 115-132.

Pintér, Z., Molnár, A., Szász, A., Kiss, G., Orbán, K., Varga, Cs., László, F., Molnár, E., Pálfi, Gy. (2013): Reliability of anthropometric parameters in the prediction of the visceral fat area among adult women. Anthropol. Anz., 70(2): 147-164. DOI: 10.1127/0003-5548/2012/0238

Pósa, A., Kupai, K., Ménesi, R., Szalai, Z., Szabó, R., Pintér, Z, Pálfi, Gy., Gyöngyösi, M., Berkó, A., Pávó, I., Varga, Cs. (2013): Sexual dimorphism of cardiovascular ischemia susceptibility is mediated by heme-oxigenase. Oxidative Medicine and Cellular Longevity, 2013: 521-563. DOI: $\underline{10.1155 / 2013 / 521563}$

Levelezési cím: $\quad$ Pintér Zoltán

Mailing address: Szegedi Tudományegyetem, Természettudományi és Informatikai Kar

Embertani Tanszék

Közép fasor 52.

H-6726 Szeged

Hungary

pinterster@gmail.com 